\title{
Small, medium and micro-enterprises' distress and factual evaluation of rescue feasibility
}

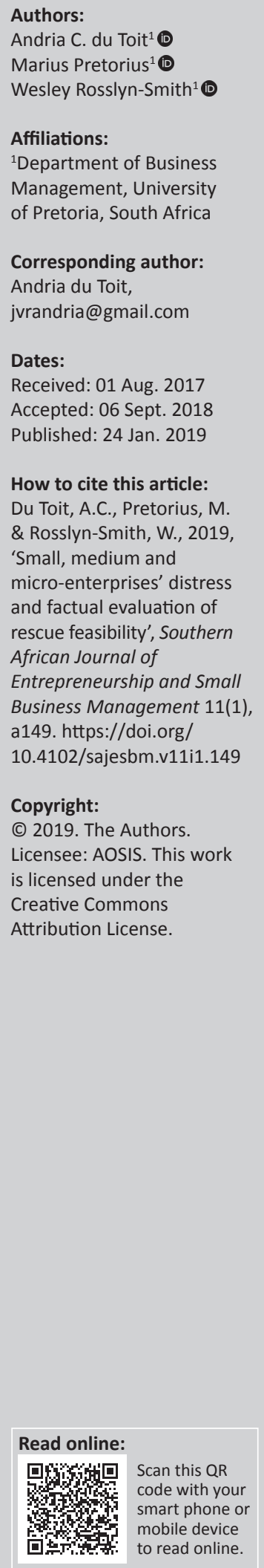

Background: Entrepreneurs often face distress in their businesses; as one way to address it, they can file for business rescue. The Companies Act 71 of 2008 requires the appointed business rescue practitioner (BRP) to place before the court facts proving 'reasonable prospect'. This often seems determined mainly by the subjective opinion of practitioners, who rely on their experience and knowledge in rescue and business management. This appears to be in direct contrast to the requirements for factual evidence set out by several court judgements. There are many questions surrounding the determination of reasonable prospect, as there seems to be no benchmark for entrepreneurs and BRPs to work towards or a prescribed process to be followed.

Aim: This article investigates different methods of factually determining reasonable prospect and guiding the decision-making process during the pre-filing and initial stages of the rescue of small, medium and micro-enterprises (SMMEs).

Setting: The study was conducted using South African case law and financial models relevant to SMMEs in South Africa.

Methods: Qualitative analysis of existing financial models and case law to better understand how BRPs determine initial reasonable prospect when working with SMMEs.

Results: The research report methods of determining financial distress and decline within the relevant case law.

Conclusion: Reasonable prospect relies heavily on experience and opinion. Factually proving reasonable prospect remains problematic because of information asymmetry and the lack of data integrity. Affected parties (including entrepreneurs) could benefit from the insights obtained in this study. Identifying methods that could assist with the factual determination of reasonable prospect could contribute to entrepreneurial education, as well as address the current conflict that surrounds the subject.

'Change is not a threat, it's an opportunity. Survival is not the goal; transformative success is.' Seth Godin

\section{Introduction}

According to the Regulator's quarterly report of 30 September 2015, the number of business rescue filings (the bulk of which were SMMEs) amounted to 1121 between 2011 and 2014 (an average of 39 filings per month), with only 270 reported cases that ended in the termination of business rescue proceedings (section 132[2][b]) or the substantial implementation of the business rescue plan (section 132[2][c][ii]). This emphasises the intense need for improved business rescue practices to increase the number of businesses that leave rescue successfully.

As prescribed by the Companies Act 71 of 2008 (hereafter referred to as the Act), section 129(1)(a) and (b), the presence of financial distress and reasonable prospect (of rescue) must be evident in order for a business to file for rescue (Conradie \& Lamprecht 2015:2; Gribnitz \& Appelbaum 2015:99). Business rescue practitioners (BRPs) and affected parties struggle to determine these variables. To a large extent, they depend on subjective thought processes, which differ from one individual to the next, contributing to the accumulation of conflict in the industry (Baird \& Lorence 2012). Affected parties (section 128[a]) are regularly forced to make important decisions on a matter such as reasonable prospect, under liabilities of information asymmetry and poor data integrity (Lee et al. 2004:89; Pretorius \& Holtzhauzen 2008:100; Wang 1998:60).

For the purposes of this study, the reasonable prospect is described as the initial evaluation by the BRP to determine the immediate prospect of the SMME (feasibility of the possible rescue). 
It is also of critical value to entrepreneurs and SMME owners who, when filing, must officially declare their business in distress and their belief that reasonable prospect exists. Thus, prospect remains the main driver for the BRP to undertake the rescue and/or the court to place the business under rescue. It is important to note that reasonable prospect is dynamic in nature and must be evaluated continuously throughout the rescue proceedings.

By completing an in-depth study of relevant literature and other written works on the subject, the researchers were able to determine the aspects of reasonable prospect and different methods from the law, finance and management perspective in business rescue and its related decision-making processes. Understanding of this complex phenomenon could clarify the comprehensive thought process followed during the business rescue process and decision making by practitioners. Business rescue, as a young industry, could benefit from improved guidelines for decision making, especially those regarding initial reasonable prospect.

The purpose of this article is to identify and explore methods available to entrepreneurs and the BRP during investigation and determination of the distressed company's initial reasonable prospect.

\section{Literature review}

\section{Business rescue: Short history and overview}

Formal turnaround management from a South African perspective is still in its early stages (Holtzhauzen 2010:29). Judicial management, a form of formal turnaround (Loubser 2010:2), was first introduced in South Africa in 1926 and was widely regarded as unsuccessful because it presented no catalyst to pursue rehabilitation of the organisation over liquidation. Nevertheless, the Van Wyk de Vries Commission regarded it as sufficiently helpful to recommend that it be retained in the 1973 Companies Act (Joubert 2013:552). In the light of mounting international pressure, South Africa introduced a modern turnaround regime, known as business rescue (Chapter 6 of the Companies Act 71 of 2008) (Burdette 2011; Rosslyn-Smith \& Pretorius 2015:8).

Business rescue, as defined by the Act, refers to the proceedings to facilitate the rehabilitation of a company that is financially distressed by providing for the temporary supervision of the company and the management of its affairs, business and property, as well as a temporary moratorium on the rights of claimants against the company or in respect of the property in its possession (Chapter 6 of Companies Act 71 of 2008).

The initial objective of business rescue is to keep companies alive in order to extract greater value for stakeholders such as employees, shareholders and creditors (Conradie \& Lamprecht 2015:2; Joubert 2013:550). Business rescue can also serve a second objective, in that when there is no possibility of rehabilitation of the firm and its continuing existence on a solvent basis, the business rescue will result in better returns for creditors and affected parties (section 128[1][b][iii] of the Act), compared with the returns from an immediate liquidation (Levenstein 2008:13).

Chapter 6 of the Act came into effect on 1 May 2011, allowing rescue procedures vaguely comparable to those of Chapter 11 in the United States (Balovich 2002) and administration in the United Kingdom (Parliament of the United Kingdom 2006). According to Chapter 6 of the Act, in order to file for business rescue, firms must be 'financially distressed'. The meaning of financially distressed as defined in section 128(1)(f) includes the requirement that the company is unable to pay creditors or will become unable to pay creditors in the next 6 months (Levenstein 2008:12).

The Act describes the following two ways of entering business rescue: the first option is voluntary filing by the board of the company (section 129[1]) if the company adheres to the requirements set out in section 129(1)(a) and (b). The second option described is an application to court by an affected person (section 128[a]) to place the company under supervision and commence rescue proceedings. It is important to note that in both cases reasonable prospect is a requirement. After considering the application, the court may decide to place the company in business rescue if the requirements of section 131(4)(a) are met or to dismiss the application according to section 131(4)(b) (Conradie \& Lamprecht 2015:5).

During voluntary filing, the distressed company nominates (section 129[3][b]) a BRP in accordance with section 138, or the affected person (section 131[5]) who brought about the court application, or the court (interim BRP) may nominate a BRP in accordance with section 138 of the Act. A BRP is an independent and qualified person who acts as an officer of the court (section 140[3][a]) as prescribed by the Act and is appointed to navigate the company back to financial health, so that it continues to exist on a solvent basis (Conradie \& Lamprecht 2015:5).

The BRP is required to bring a variety of skills to the business (Pretorius 2014). As an officer (agent) of the court, the BRP has the responsibilities, duties and liabilities of a director of the company, as set out in sections 75 (financial interests), 76 (conduct) and 77 (liabilities) of the Act. All the above takes place within the 'supreme task' of compliance with the Act and its procedures (Pretorius 2014). The BRP has total control of the firm until he or she presents the plan to the creditors, when the power is shifted to the creditors via their votes. If the creditors vote in favour of the business rescue plan, the rescue proceedings continue and the BRP is in control again, implementing the plan to rescue the company by restructuring its affairs, business, property, debt and other liabilities, and equity (Pretorius \& Rosslyn-Smith 2014).

A business rescue plan has various requirements and standards to uphold, and it plays an integral part in the 
successful turnaround of the business. Twenty-five business days, with possible extensions, are granted to the BRP after appointment to formulate and disclose a feasible business plan. The objective of the plan is to detail the procedures and strategies to be used for the company to overcome its financial adversities and resume normal commercial operations on a solvent basis (Pretorius \& Rosslyn-Smith 2014:27). In the event that this is not possible, the implementation of the proposal must result in a better return for the company's affected parties than would result from immediate liquidation of the company. Section 150 of the Act prescribes the content to be presented in the business rescue plan. The overarching mandate is to provide satisfactory direction to the affected parties for them to reach a judgement regarding its ratification. Section 150(2) details distinct fundamentals to be included in the document; however, these only result in the bare minimum required for compliance, and it is generally accepted that the plan should go beyond them (Pretorius \& Rosslyn-Smith 2014:29).

All the above can only take place if reasonable prospect was established at the onset of the process.

\section{Asymmetric information and lack of data integrity}

Decision making during business rescue depends on the quality of information provided (Pretorius 2014:9). Data integrity refers to correctness, completeness, wholeness, reliability and truthfulness of the data available for decision making (Lee et al. 2004:89; Wang, Ziad \& Lee 2006:60). For more than a century, formal economic models of decisionmaking mechanisms were based on the hypothesis of perfect information, where information asymmetries were rejected (Connelly et al. 2011:42). Asymmetry of information is said to exist when one party to a transaction possesses more information than the other. According to Stiglitz (2000), there are two types of information where asymmetry is particularly relevant, namely information about quality and information about intent.

In the business rescue industry, internal data used for critical decision making are often subject to misrepresentation, obscuring and suppression for several reasons (Pretorius \&Holtzhauzen 2008). Examples include inflated debtors' data to improve balance sheets, overestimated sales projections that inflate demand figures, manipulated inventory projections, overvalued assets, incorrect attribution of causes to protect positions and the withholding of certain information to protect vulnerable projects and questionable decision making from the past. Although some of these might be intentional, there are also some that are unintentional because of biases, heuristics or perceptive shortcuts in the perception of those presenting it (Pretorius \& Holtzhauzen 2008:100).

There are two main types of data needed during the business rescue process: financial data, including income statements, balance sheets and transaction records, and management records, such as supply reports and data interpretations (Lee et al. 2004:90) - which are highly susceptible to inaccuracies and human error, limitations and biases. Verification and authentication of data is a time-consuming process, and time is not abundantly available during business rescue. Data integrity therefore depends on the BRP's ability to verify and authenticate data for decision making. The reluctance to verify data regularly leads to assumptions and contributes to poor strategy choices (Pretorius \& Holtzhauzen 2008:101).

An argument by Barker and Barr (2002:963) highlights the fact that top management has a large impact, as the key contributor to the downswing and ultimate failure of the business if it fails to adapt strategies. Top management's apprehensions are important influences on decisions affecting organisational performance. These authors suggest that the way in which the top management team perceives the causes of failure determines the extent of its recovery actions (Pretorius \& Holtzhauzen 2008:101). BRPs are dependent on the apprehensions of management, which is a fundamental source of information.

Management may frame the requested information according to self-serving benefits or the members' specific knowledge structures, influencing the data integrity. Management's beliefs are also contingent on subjective opinions of subordinate management through overconfidence (Shepherd 2005:125), escalation of commitment (Shepherd 2005:129), risk perception and misconceptions (Le Roux, Pretorius \& Millard 2006). In order to succeed in rescuing a deteriorating firm, the practitioner must identify and conquer these obstacles. According to Engelbrecht (2014), in order to identify foul play in financial statements, it is advisable that the practitioner compare statements with at least 6 months' formal banking transaction statements. In doing so, the practitioner (or his accountant) may promptly determine whether the provided data mirrors the true position of the firm, before commencing with reasonable prospect determinations and calculations.

\section{Reasonable prospect}

As discussed by Pretorius (2014), judging reasonable prospect is a major source of conflict between different parties in the business rescue industry. Distinguishing reasonable prospect relies on numerous moderators and mediators of judgement, and the opinions of individuals clash frequently, as there is no standardised method for determining reasonable prospect, which is mentioned in the Act but not clearly defined.

'Reasonable prospect' (a term not defined in the Companies Act) does not necessarily mean reasonable possibility; however, it means a prospect based on reasonable grounds and not speculative suggestions or vague averments (Southern Palace Investments 265 [Pty] Ltd v Midnight Storm Investments 386 [Pty] Ltd). The presence of reasonable prospect is a prerequisite for business rescue practices to commence, and the reliability of the information used to determine reasonable prospect is crucial to ensure the trustworthiness of the prospect being determined. 
An applicant is required to place before the court a factual foundation for the existence of a reasonable prospect: that business rescue is likely to achieve the primary object or the secondary object of business rescue. Whether or not 'reasonable prospect' has been established is a factual inquiry to be made on a case-by-case basis, bearing in mind that the primary object of business rescue is to facilitate the continued existence of a company that is in a state of insolvency (section 128[1][b][iii]); the secondary object of business rescue is, in the event that the primary object is not viable, to facilitate a better return for the creditors of a company (section 128[1][b] [iii]), as described in the Act.

Currently, reasonable prospect often depends on subjective thought processes with no formal framework of objective facts that can be used to ratify it from a business perspective (Oakdene Square Properties [Pty] Ltd and Others v Farm Bothasfontein [Kyalami] [Pty] Ltd [SCA]). The reluctance of affected parties to share reliable financial and/or other information contributes to the stagnant and complex process. Courts have to decide whether distressed businesses are to be liquidated or placed into rescue, using mainly the subjective opinions of rescue practitioners and/or opposing parties in court.

We proceed by highlighting the research methodology of the current study, with emphasis on the researchers' epistemology and ontology.

\section{Methodology Epistemology}

With the objective of answering the research questions in mind, the researchers were aware of their own methodological beliefs (including values and assumptions) and the fact that these beliefs would unmistakably influence their research and probably create bias in interpreting the data. The following information is provided to inform the reader about the 'intellectual climate' in which the research was conducted.

The theory of knowledge (epistemology) of the researchers describes how one can discover underlying principles about social phenomena and clearly shows the existence thereof (Pretorius \& Holtzhauzen 2013:474). The interpretive (constructionist) paradigm was followed during this research - it focuses on the world from the point of view of an individual or group interacting in and with it (Denicolo \& Becker 2012). Interpretivist research can also be described as research with collectiveness; descriptive or qualitative research is usually conducted when theory or previous research is lacking. In this case, the factual determination of (initial) reasonable prospect in business rescue has only been researched vaguely. Interpretive research emphasises the understanding of a social reality in a specific context, from the participants' view of sense making. This paradigm depicts multiple realities, depending on the context and content of the situation, demanding a holistic approach to address the variables in the system being analysed. Hypothesis testing is not relevant in this paradigm, but the answering of the research questions stated is of utmost importance. The data will more often be qualitative in nature (Berniker \& McNabb 2011), but the paradigm does not exclude quantitative data or findings. Verification of data is important and can be accomplished by comparing findings from different sources through triangulation (Decorp 1999); for example, comparing findings of interviews with findings of observation or questionnaire responses (Denicolo \& Becker 2012).

For this study, the researchers preferred the interpretivist over the positivist paradigm, because they set out to uncover the practices of BRPs and not a relationship that might occur as a result of certain phenomena during the business rescue process.

\section{Ontology}

The ontological position consists of the researchers' views on the very nature and essence of research reality (Maedche 2002:13). The researchers are acceptant rationalists (Katz 1998), who believe that knowledge sprouts from overlapping findings after investigations or experimentations by numerous individuals in different situations. If these findings support one another, they can be seen as patterns, some of which may form precedents. Rationalism views the main source and test of knowledge to be reason; the theory in which the criterion of truth is not sensory but intellectual and deductive - reality has a logical structure.

We pursued open-minded, non-biased analysis of data. An acceptance of the findings, even when against one's beliefs and norms, is critical to deliver conclusions congruent with actual practice. If a researcher finds it difficult to conduct objective research, structured data-gathering methods are a safe choice to prevent contamination of the study, and these were opted for in this research. Causes and responses differ in certain situations, and patterns are not always black or white; grey areas (multiple realties) do exist and need to be addressed as well. The context and content of a situation influences studies, which cannot rely on simple observations (Loewenstein, Thompson \& Bazerman 1989).

The research design followed is presented here by means of a shortened Yin Table 1.

\section{Findings}

Law, finance (accounting) and management are important perspectives in business rescue procedures and a working knowledge of these fields does benefit the BRP in his or her endeavours. It is also important to understand the different approaches followed by these perspectives when (initial) reasonable prospect is the topic at hand.

There are relevant methods and calculations reported in the various bodies of knowledge available to BRPs from a 
TABLE 1: Summarised research design components.

\begin{tabular}{|c|c|}
\hline Component & Description \\
\hline Research problem & $\begin{array}{l}\text { As described in the Companies Act } 71 \text { of } 2008 \text {, the } \\
\text { presence of financial distress and reasonable prospect } \\
\text { must be evident in order for a business to file for } \\
\text { rescue. Financial distress is clearly defined in section } \\
128(1) \text { (f) of the Act, but reasonable prospect has no } \\
\text { clear definition or guidelines. Business rescue } \\
\text { practitioners (BRPs) and affected parties struggle to } \\
\text { determine this variable, as the decision largely } \\
\text { depends on a subjective thought process, which } \\
\text { differs from one individual to the next. This is a source } \\
\text { of conflict in the industry. By investigating methods } \\
\text { from three perspectives relevant to business rescue, } \\
\text { factual evidence may be derived to support the } \\
\text { determination of initial reasonable prospect in small, } \\
\text { medium and micro-enterprises (SMMEs). }\end{array}$ \\
\hline Research question 1 & What is reasonable prospect in business rescue? \\
\hline Research question 2 & $\begin{array}{l}\text { How can reasonable prospect be determined factually } \\
\text { in SMMEs? }\end{array}$ \\
\hline Context & $\begin{array}{l}\text { BRPs (and other parties) estimating the extent to } \\
\text { which an organisation has deteriorated and the } \\
\text { probability of turning the organisation around, in the } \\
\text { initial stages of the rescue process. }\end{array}$ \\
\hline $\begin{array}{l}\text { Phenomenon investigated } \\
\text { (Unit of analysis) }\end{array}$ & $\begin{array}{l}\text { Reasonable prospect and its factual measurement in } \\
\text { SMMEs. }\end{array}$ \\
\hline Method & $\begin{array}{l}\text { Intense analysis of existing financial models and case } \\
\text { law to better understand how BRPs determine initial } \\
\text { reasonable prospect when working with SMMEs. }\end{array}$ \\
\hline $\begin{array}{l}\text { Logic linking the data to the } \\
\text { research questions }\end{array}$ & $\begin{array}{l}\text { Reasonable prospect is the basis for determining the } \\
\text { possibility of rescue and should be well understood } \\
\text { and agreed upon (to a degree) in order to establish a } \\
\text { well-developed process or system of business rescue } \\
\text { in South Africa. Identifying methods of determining } \\
\text { reasonable prospect could assist BRPs and contribute } \\
\text { to business rescue. Therefore, we propose research in } \\
\text { this area by studying relevant literature on different } \\
\text { factors that might assist BRPs to determine the } \\
\text { reasonable prospect of rescuing a distressed SMME. }\end{array}$ \\
\hline
\end{tabular}

Source: Yin, R.K., 2003, Case study research. Design and methods: Applied social research methods, 3rd edn., Sage, London.

finance (accounting) and management perspective. For the purpose of this article, we focused on more practical methods used to measure business decline and sustainability in SMMEs. Altman (1968; Altman \& Narayanan 1997) followed a more pessimistic approach when developing the Z-score to predict business decline, whereas Timmons and Spinelli (2003) chose a more optimistic approach, identifying the elements essential for a business to exist. The courts, however, only require that the evidence should be factual. We expand on this in the next section.

\section{Law perspective}

The first reported business rescue judgement was on 30 May 2011 (the same month that the new Act came into effect) and was made by Judge Makgoba in RA Swart $v$ Beagles Run Investments 25 (Pty) Ltd. The matter was brought and decided on an argument basis and was contended by creditors as an abuse of process. The creditors argued that the application was the climax of attempts by the firm to sidestep debtors' payments. Makgoba ruled in favour of the creditors and argued that the interests of creditors should carry the day, if they are weighed against the interests of the firm itself. Makgoba also argued that the requirement of a 'reasonable prospect' for rescuing a company must mean a 'reasonable probability' of rescue; he then went on to follow the law relating to the judicial management of companies, which was the previous regime for financially distressed companies in South Africa, abolished by the provisions of the new Act. In the exercise of his discretion, after weighing the facts as to whether there was such a 'reasonable probability' of rescue, Judge Makgoba denied the application for business rescue to proceed.

Unsurprisingly, the judgement that became the locus classicus of judicial interpretations of the requirements for business rescue applications did not follow Makgoba when it was handed down 6 months later by Judge Eloff in the Southern Palace Investments 265 (Pty) Ltd v Midnight Storm Investments 386 (Pty) Ltd. Eloff argued that the requirements for reasonable prospect of recovery must mean something less than that and the partial recovery should be a 'reasonable probability'. The judge remarked that the business rescue provisions heralded a new era and that the old mindset of the creditor being almost entitled to a winding-up order, as if of right, was inappropriate. Business rescue was to be preferred to liquidation. However, even though he held that the substantive test (referring to the requirements of section 129[1]) that must be adhered to has a lower threshold than for judicial management, it still lies within the discretion of the court whether or not to grant an application for business rescue. The requirements of a 'reasonable prospect' for rescuing the company must be read with the definition of business rescue, section 128(1)(b). If the applicant stated that the company would recover, the court demands that such allegations must contain some 'concrete and objectively ascertainable details going beyond mere speculation' of the following facts: the probable costs of rendering the company capable of resuming its business, the probable availability of the necessary cash resources and any other resources necessary, and why the proposed plan would have a reasonable prospect of success. On the facts (or the lack thereof), the application was denied.

As mentioned by Floor (2013), the Southern Gauteng High Court in Oakdene Square $v$ Farm Bothasfontein (Kayalami) denied the application to place the company that owned the Kayalami race track under business rescue and ruled that the dearth of recent financial statements would make it improbable for the BRP to successfully restructure the operations of the company. The court also sanctioned the indication by the majority of shareholders that they would vote against any manifestation by the BRP.

In another court case, AG Petzetakis International Holdings Ltd $v$ Petzetakis Africa (Pty) Ltd, the court found, based on the facts available to the court, that the company under discussion was beyond rescue unless it received a large financial injection (otherwise known as post-commencement finance); there was no indication present that such a financial injection would be forthcoming. Therefore, the court denied the application to be put under business rescue because of there being no reasonable prospect.

The prospects for a successful rescue may vary from case to case; as a general rule, however, the company filing for business rescue is required to present objectively ascertainable details showing that the company has a reasonable prospect 
of being rescued successfully (Floor 2013). What those details entail, however, is not stated.

Based on the court cases mentioned, factual, concrete, objective and ascertainable details appear to be the basic requirements. The evidence reported in these cases points to the absence of these, hence the research questions of this study. This article proceeds to integrate literature on businessrelated tools to determine reasonable prospect in SMMEs under significant time constraints.

\section{Business management perspective}

In order for the BRP to determine the feasibility of a rescue, he or she must determine whether the distressed SMME at hand has all the components needed to function as a profitable business after the proposed rescue proceedings have ended. Some of these components can be introduced during the rescue if they are absent, whereas others are integral to the existence of a business at the start of rescue proceedings and cannot be added later on during the life cycle of the business. Relevant (basic) entrepreneurial and business management principles are helpful to define these components.

\section{Opportunity analysis}

The main objective of the Opportunity Analysis (OA), as broadly discussed by Timmons and Spinelli (2003:79-113), is to establish whether an opportunity exists for doing meaningful business. The analysis explores six areas of opportunity, unexampled for every business in its specific context. The OA originated when research was conducted on new business opportunities and the buying or selling of an existing business, and we considered it applicable for determining the presence of reasonable prospect under distress situations in businesses. The start-up opportunity appears closely related to the rescue opportunity and therefore might enhance the understanding of reasonable prospect.

During the OA, all aspects of the business are looked at separately, dividing all operations into five main business model groups, namely: demand for concept offering (value propositions), team and resources, competitive environment (profitability) and finance. The OA then judges the potential of the proposed start-up venture through its feasibility. By using this analytical approach for a distressed firm where the same principles apply, the weakest link in the business chain can be identified and improved to obtain better returns or to establish reasonable prospect. The OA lends itself to the use of determining reasonable prospect from a feasibility perspective, as it questions whether the elements crucial for a reorganised business to exist are present at the specific time (Nieman \& Pretorius 2004).

An opportunity scorecard can be used to analyse the different business elements of a venture (Choi \& Shepherd 2004; Shepherd 1999). The scorecard includes the following fields of analysis: value proposition and venture support, product or solution demand, competitive environment, economic model, cash-flow issues and managerial resource fit. Each of these elements can be judged and then interpreted accordingly, ranging from an excellent opportunity to a dangerous opportunity.

\section{The 'Do we have a business?' test}

The 'Do we have a business?' test (DWaB test) was built on the foundations of the feasibility principles and the OA and still builds on the pillars provided by these analytical methods. Basically, the 'test' comprises five questions, covering the elements needed for a business to exist, to be answered by a reasonable and experienced business person. These elements must be properly managed in order for the venture to be operated profitably (Timmons \& Spinelli 2003:79-113).

The questions covered in the test include whether there is demand for the product and/or service. This refers directly to the concept offering and the significance of the demand for this. This demand can be defined as the utility of goods or service from an economic agent. Does the capacity exist to deliver on the demand? Capacity can also be described as the output capability over a specific period, infrastructure and the human resource capacity. Is there a profitable business case in motion? This question refers to the reasoning behind initiating the business or project and whether there is economic logic supporting the business model. Are the cashflow projections positive? This can be described as the amount of liquidity moving through the business and/or the ability of the business to pay immediate creditors. Are there potential flaws (caveats) in the business model that may render the other factors useless? These caveats can be any constraints to the optimal functioning of the business. These questions are progressive in that a negative answer to one can have an eliminating power.

This analysis overlaps with the OA, previously explored, to a large extent suggesting that the elements to be tested are the right ones. These models focus on the requirements of early judgements concerning feasibility to be followed up by validity testing and due diligence type analyses (Gillman 2001).

\section{Financial management (accounting) perspective}

As set out in the introduction of this article, the definite presence of financial distress is required for business rescue proceedings to commence. Therefore, the study also explored some popular methods of determining distress from a financial perspective, namely financial ratios, the Altman Z-score and discriminant models, as well as general cashflow ratios as predictors.

\section{Financial ratio analysis}

When analysing traditional financial or accounting ratios, a definite variation can be observed between the ratios of financially healthy and deteriorating firms (Altman 1968:590). Altman's study implied a definite potential of ratios as 
TABLE 2: Financial ratios: Determining the main problem areas of a distressed business.

\begin{tabular}{|c|c|c|}
\hline Ratio & Formula & Description \\
\hline Profitability & $\begin{array}{l}\text { - Gross profit margin = gross } \\
\text { income } \div \text { sales } \\
\text { - Operating profit margin = } \\
\text { operating income } \div \text { sales } \\
\text { - Net profit margin = net } \\
\text { income } \div \text { sales }\end{array}$ & $\begin{array}{l}\text { Profitability ratio shows the amount } \\
\text { of each sales unit (in percentage) left } \\
\text { after all expenses have been paid. } \\
\text { It is very useful when comparing } \\
\text { companies in similar industries. A } \\
\text { higher profit margin indicates that } \\
\text { a company is more efficient at } \\
\text { converting sales into actual profit. }\end{array}$ \\
\hline Liquidityஸ̀ & $\begin{array}{l}\text { - Current ratio }=\text { current } \\
\text { assets } \div \text { current liabilities } \\
\text { - Quick ratio }=\text { current assets - } \\
\text { inventory } \div \text { current liabilities } \\
\text { - Net working capital to sales } \\
\text { ratio }=\text { current assets }- \\
\text { current liabilities } \div \text { sales }\end{array}$ & $\begin{array}{l}\text { Liquidity ratios measure the ability of } \\
\text { the company to meet its short-term } \\
\text { debts when they fall due. }\end{array}$ \\
\hline Solvency' & $\begin{array}{l}\text { - Solvency ratio }=\text { after-tax net } \\
\text { profit }+ \text { depreciation } \div \text { total } \\
\text { liabilities }\end{array}$ & $\begin{array}{l}\text { Solvency ratios measure the } \\
\text { company's ability to meet its long- } \\
\text { term debts when they fall due. }\end{array}$ \\
\hline
\end{tabular}

Source: Altman, E., 1968, 'Financial ratios, discriminant analysis and the prediction of corporate bankruptcy', Journal of Finance 13(4), 589-609. https://doi.org/10.1111/j.15406261.1968.tb00843.x

$\dagger$, Liquidity and solvency are also the key elements for legal arguments as they govern insolvency law.

'predictors of bankruptcy'. The most significant indicators include ratios measuring profitability, liquidity and solvency as shown in Table 2.

Although viewed as a handy tool for measuring the financial position of a firm, ratios can be susceptible to 'faulty interpretation and [be] potentially confusing' (Altman 1968:591). Any ratio analysis needs to be done in accordance with the specific industry of the firm. Comparing ratios of two firms from contrasting industries would be idle. Other major determinants of effective measurement through ratios are the size of the firm and the current economic climate in which it operates. Financial ratios tend to deflate ratio statistics and therefore a large part of the size effect may be lost.

In essence, when calculating ratios of a firm, one embarks on an in-depth analysis of the firm's results compared with the industry benchmark or norm, taking into account the size of the firm as well as the current economic climate prevailing at the time (Jooste 2006:7). Analysing ratios depend on financial figures (data) that are trustworthy, following some viability testing and potentially due diligence (Gillman 2001:3). The existence of reasonable prospect is required mostly before such processes have been embarked upon, thus it is associated with early feasibility judgements. Financial ratios are a handy tool to be used by BRPs to determine the area of distress in a business, after which it might be easier to establish reasonable prospect.

International Financial Reporting Standards (IFRS) are principles-based standards, interpretations and the framework adopted by the International Accounting Standards Board. International Financial Reporting Standards represent a set of internationally accepted accounting and financial management procedures, which have been required from all South African listed firms since 2005 (available online: http:/ /www.ifrs.org/Pages/default.aspx).

\section{Multiple discriminant analysis and the Z-score analysis}

Multiple Discriminant Analysis (MDA) has been regarded as the most popular technique (Altman \& Narayanan 1997:2) to predict financial failure among firms, as researchers have tested numerous other techniques with disappointing outcomes. Multiple Discriminant Analysis seems to be the de facto benchmark for the comparison of distress prediction models for various reasons (Altman \& Narayanan 1997:2). It is important to view Altman's Z-score model hand-in-hand with the MDA model; Edward Altman is famous for using discriminant analysis in developing his renowned Z-score analysis.

The discriminant function used is as follows (Altman 1968:594; Paston, Harmon \& Gramlich 2011:46):

$Z=0.012 X 1+0.014 X 2+0.033 X 3+0.006 X 4+0.999 X 5 \quad[$ Eqn 1$]$

where $\mathrm{X} 1=$ Working capital/Total assets, $\mathrm{X} 2=$ Retained earnings/Total assets, $\mathrm{X} 3=$ Earnings before interests and tax/Total assets, $\mathrm{X} 4=$ Market value of equity/Book value of total debt, $X 5=$ Sales /Total assets and $Z=$ Overall index + Once the $Z$-score has been determined, it is compared with Table 3 for interpretation.

When interpreting the Z-score, evaluators are required to be cognisant of two issues: firstly, less time and effort would be spent on firms scoring a high Z-value (> 3.0) than firms scoring low Z-values and would signal a very thorough investigation (Altman 1968:608). Secondly, firms scoring a $Z$-value under the 'zone of ignorance' experience a decline in their stock of up to $45 \%$, from date of analysis to date of actual failure, an average period of 15 months where documented (Altman 1968:608).

In 1997 Altman published an evolved version of the Z-score model, which provides the opportunity for companies under analysis to be grouped into two homogeneous categories, namely developed country models, characterised by the detailed history of prediction failure, accessible corporate financial data, minimal government intervention and sophisticated regulations to protect investors; and developing country models, characterised by the absence of a free market economy, greater government interference and the absence of conditions prevalent in developed countries (Altman \& Narayanan 1997:3).

Altman also used a larger amount of financial data to investigate the firms and found that models with several years of data available outperformed a similar model (model of 1968) with data from only 1 year prior to failure (Altman \& Narayanan 1997:6). The use of absolute financial statements (1-8 years), provided by an external accounting firm, contributed to the accuracy of classification - it is of absolute importance that the data used are reliable and a true version of the actual operations within the business. In business rescue, however, such data are rarely available. Moreover, data integrity has proved to be lacking in most cases (Pretorius \& Holtzhauzen 2008). 
TABLE 3: Interpretation of the Altman Z-score.

\begin{tabular}{|c|c|}
\hline Z-score & Description (Indicator of) \\
\hline$>2.99$ & Healthy \\
\hline$<1.81$ & Bankrupt (Failed) \\
\hline $1.81-2.99$ & Zone of ignorance/Grey zone; susceptible to error \\
\hline 2.675 & $\begin{array}{l}\text { 'Midpoint' in 'zone of ignorance', Z-value that discriminates best } \\
\text { between bankrupt and healthy firms }\end{array}$ \\
\hline
\end{tabular}

Source: Paston, K.M., Harmon, W.K. \& Gramlich, J.D., 2011, 'A test of financial ratios as predictors of turnaround versus failure among financially distressed firms', Journal of Applied Research 10(1), 47.

TABLE 4: Cash-flow ratios (healthy vs. distressed).

\begin{tabular}{|c|c|c|}
\hline Type of ratio & Ratio calculation & Description \\
\hline \multirow[t]{6}{*}{$\begin{array}{l}\text { Sufficiency ratios: } \\
\text { Ability of firm to } \\
\text { provide cash for its } \\
\text { cash requirements }\end{array}$} & $\begin{array}{l}\text { 1. Cash-flow adequacy }= \\
\text { CFFO } \div \text { long-term debt } \\
+ \text { purchases of assets } \\
+ \text { dividends paid) }\end{array}$ & $\begin{array}{l}\text { Evaluates the ability to } \\
\text { generate sufficient cash to } \\
\text { meet primary obligations }\end{array}$ \\
\hline & $\begin{array}{l}\text { 2. Long-term debt } \\
\text { repayment }=\text { Long-term } \\
\text { debt payments/CFFO }\end{array}$ & $\begin{array}{l}\text { Evaluates the sufficiency of } \\
\text { cash flow to settle long-term } \\
\text { debt }\end{array}$ \\
\hline & $\begin{array}{l}\text { 3. Dividend pay-out }= \\
\text { Dividends } \div \text { CFFO }\end{array}$ & $\begin{array}{l}\text { Evaluates the sufficiency of } \\
\text { cash flow to pay dividends }\end{array}$ \\
\hline & $\begin{array}{l}\text { 4. Reinvestment }=\text { Purchases } \\
\text { of assets } \div \text { CFFO }\end{array}$ & $\begin{array}{l}\text { Evaluates the sufficiency of } \\
\text { cash flow for reinvestment } \\
\text { and maintenance of asset } \\
\text { structure }\end{array}$ \\
\hline & $\begin{array}{l}\text { 5. Debt coverage }=\text { Total } \\
\text { debt } \div \text { CFFO }\end{array}$ & $\begin{array}{l}\text { Estimates the number of } \\
\text { years to repay debt at the } \\
\text { current level of cash flow }\end{array}$ \\
\hline & $\begin{array}{l}\text { 6. Impact of depreciation of } \\
\text { write-offs }=\text { (Depreciation } \\
+ \text { amortisation) } \div \text { CFFO }\end{array}$ & $\begin{array}{l}\text { Evaluates the } \% \text { cash from } \\
\text { operating activities because } \\
\text { of adjustments and amounts } \\
\text { written off }\end{array}$ \\
\hline \multirow{3}{*}{$\begin{array}{l}\text { Efficiency ratios: Extent } \\
\text { to which cash is } \\
\text { generated over time } \\
\text { and relative to other } \\
\text { companies }\end{array}$} & $\begin{array}{l}\text { 7. Cash flow to sales }=\text { CFFO } \\
\div \text { Sales }\end{array}$ & $\begin{array}{l}\text { Indicates the } \% \text { of each rand } \\
\text { sale from operating activities } \\
\text { which is realised in cash }\end{array}$ \\
\hline & $\begin{array}{l}\text { 8. Operating index }=\text { CFFO } \\
\div \text { Income from continuing } \\
\text { operations }\end{array}$ & $\begin{array}{l}\text { Compares cash flow from } \\
\text { operating activities with } \\
\text { income from continued } \\
\text { activities }\end{array}$ \\
\hline & $\begin{array}{l}\text { 9. Cash-flow return of assets } \\
=\text { CFFO } \div \text { Total assets }\end{array}$ & $\begin{array}{l}\text { Evaluates the cash flow from } \\
\text { assets utilised }\end{array}$ \\
\hline
\end{tabular}

Source: Giacomino, D.E. \& Mielke, D.E., 1993, 'Cash flows: Another approach to ratio analysis', Journal of Accountancy 175(3), 55.

CFFO, Cash flow from operations.

The Altman Z-score is a handy tool when failure prediction is the main objective of the BRP (Altman 1968), but since the business is already in distress when rescue proceedings are initiated, calculating the company Z-score seems less useful, unless its aim is to use it in a scorecard for sustainable implementation. Within the realm of data integrity, or the lack thereof, one expects its application to be rare.

\section{Cash-flow ratios}

Various studies have stressed the importance of cash-flow information. Cash flow can be seen as the heart of the business and the essence of its very existence (Jooste 2006). Cash flow directly measures a firm's 'ability to pay' short- or mediumterm debt and offers amplitudes to evaluate performance. A sign of being on the continuum of failure is the problem of irregular cash flow, indicating underperformance (Boyatzis 1982). Cash-flow ratios therefore tend to measure (confirm) and support the existence of financial distress rather than indicate reasonable prospect directly.

In 1993 a study was conducted by Giacomino and Mielke to evaluate firms' performance via the use of cash-flow ratios. They sampled companies of the chemical, food and electronics industries, among the Fortune 500 (of that specific year). They calculated ratio averages over 3 years for comparison, from financial statements provided by the companies, compliant with SFAS 95. See Table 4 for a summary of cash-flow ratios they found most significant in the determination of financial health among firms in the highly related industry.

In summary, there are numerous variables prerequired for cash flow ratios (CFRs) to be useful when using cash-flow ratios as an indicator of a firm's financial health (Jooste 2006:6-10). Firstly, industry norms are required, preferably averages over three or more years, for comparison. When calculating norms, financial statements of years with similar economic climates must be used. Firms from developing countries and first-world countries cannot be compared, nor firms from different industry segments. Lastly, firms with a significant difference in size cannot be compared. Cash-flow statements can merely indicate or confirm a problem area in the business which is already in distress, not indicate reasonable prospect.

\section{Discussion}

The usefulness of the models explored in this article appears somewhat limited for determining reasonable prospect in SMMEs factually; some are less useful than others. Timmons and Spinelli's (2003) OA and DWaB test do support the determination of initial reasonable prospect but cannot be used in isolation. The IFRS liquidity and solvency ratios provide guidance to finding the origin of distress, but their usefulness regarding the determination of initial reasonable prospect is limited, yielding only vague conclusions. As regards the Altman Z-score, there are some drawbacks to applying the Z-score to determine reasonable prospect. These drawbacks include the requirement of data to calculate the Z-score, which is often lacking as a result of an asymmetry of information and lack of data integrity, and the fact that the $Z$-score is predictive in nature, whereas reasonable prospect must be determined after financial distress is already reigning.

Although there are numerous ways available to pursue initial reasonable prospect in SMMEs, the fact that data integrity is seldom guaranteed forces BRPs to exploit more than one type of analysis and/or process during their investigations. The practitioner's experience and expertise will determine which of the above analogies can be utilised, and in what combination. There will always be inaccuracy when working with data processed by individuals as a result of error and bias in human nature, but by using more than one method of analysis, this span of error can be narrowed down. Every business is unique and must be analysed as a whole in its environment and industry, compared with similar and competing organisations.

\section{Conclusion}

In conclusion, the quick but factual measurement of initial reasonable prospect in SMMEs still remains elusive. 
Reasonable prospect is a complex phenomenon and BRPs require much experience and knowledge in the different fields of business to accurately determine reasonable prospect under inadequate information conditions. The BRP's main field of experience (law, management or finance and/or accounting) may influence (bias) the perspective with which the BRP approaches the determination of reasonable prospect. These perspectives each have their own cues or signals that BRPs use to make sense during the initial stages of business rescue. By taking advantage of these signals, the uncertainties associated with asymmetric information conditions can be reduced and certain cues can be used to help guide decision making.

\section{Limitations and future research}

This article is limited to theoretical conclusions and court judgements only and includes no real-time observations by individuals in the business rescue industry. It is evident that none of the methods discussed are of any value if the data used are unreliable. Data integrity is of the utmost importance in the financial calculations and evaluation of a businesses' financial health. In order for business rescue to be successful, the determination of a trustworthy reasonable prospect is crucial, and this is only possible if the data provided is sufficient and therefore reliable and true to reality.

This study focused only on the objective (factual) ways available to determine initial reasonable prospect in SMMEs, but what about the subjective aspects of this process? Furthermore, how can the subjective determination be identified, measured and presented in courts with sufficient validity? The fact remains that the determination of reasonable prospect is required early in the business rescue process and generally in the face of a lack of data integrity after the fact of financial distress, which makes it difficult to apply 'factual detail' to support reasonable prospect. It is therefore important that research be extended to include 'human effects' in decision making, such as signalling theory and the use of heuristics.

Signalling theory could assist the process of analysing the reactions and interpretations of decision makers when working in environments of incomplete and / or asymmetric information conditions (Berg et al. 2012). Signalling theory may be of assistance during decision making in business rescue, especially during the determination of (initial) reasonable prospect, as it utilises the subjective thought process that may be of use to BRPs when factual determinations are lacking.

\section{Acknowledgements Competing interests}

The authors declare that they have no competing interests with regard to the writing of this article.

\section{Authors' contribution}

A.C.d.T. made conceptual contributions, conducted all the interviews and was largely responsible for the preparation and write up of the research. M.P was the research supervisor, made conceptual contributions and contributed substantially to the research design. W.R-S. was the research co-supervisor, made conceptual contributions and contributed to the research design.

\section{References}

AG Petzetakis International Holdings Ltd v Petzetakis Africa (Pty) Ltd and Others (2011/35891) ZAGPJHC 24; 2012 (5) SA 515 (GSJ).

Altman, E., 1968, 'Financial ratios, discriminant analysis and the prediction of corporate bankruptcy', Journal of Finance 13(4), 589-609. https://doi. org/10.1111/j.1540-6261.1968.tb00843.x

Altman, A.I. \& Narayanan, P., 1997, 'An international survey of business failure classification models', Financial Markets, Institutions \& Instruments 6(2), 1-57. https://doi.org/10.1111/1468-0416.00010

Baird, S. \& Lorence, M., 2012, 'Predicting success: A doctoral research study', Journal of Corporate Renewal, November/December, 20-23.

Balovich, D., 2002, Chapter 11 confirmation, viewed 12 March 2013, from http:// www.creditworthy.com/3jm/articles/cw42402.html

Barker, V.L. \& Barr, P.S., 2002, 'Linking top manager attributions to strategic reorientation in declining firms attempting turnarounds', Journal of Business Research 55, 963-979. https://doi.org/10.1016/S0148-2963(00)00217-4

Berg, D.D., Connelly, B.L., Ketchen, D.J. \& Shannon, L.M., 2012, 'Signalling theory and equilibrium in strategic management research: An assessment and a research agenda', Journal of Management Studies 51(8), 1334-1360. https://doi.org/ 10.1111/joms.12097

Berniker, E. \& McNabb, D.E., 2011, 'Dialectical inquiry: A structured qualitative research method', The Qualitative Report 11(4), 643-664.

Boyatzis, R.E., 1982, The competent manager: A model for effective performance, Wiley, New York.

Burdette, D.A., 2011, Legislative framework for the facilitation of turnarounds in South Africa. Turnaround management and corporate renewal: A South African perspective, Wits University Press, Johannesburg.

Choi, Y.R. \& Shepherd, D.A., 2004, 'Entrepreneurs' decisions to exploit opportunities', Journal of Management 30(3), 377-395. https://doi.org/10.1016/j. jm.2003.04.002

Connelly, B.L., Certo, S.T., Ireland, R.D. \& Reutzel, C.R., 2011, 'Signalling theory: A review and assessment', Journal of Management 37(1), 39-67. https://doi. org/10.1177/0149206310388419

Conradie, S. \& Lamprecht, C., 2015, 'Business rescue: How can its success be evaluated at company level?' Southern African Business Review 19(3), 1-28.

Decorp, A., 1999, 'Triangulation of qualitative tourism research', Tourism Management 20, 157-161. https://doi.org/10.1016/S0261-5177(98)00102-2

Denicolo, P. \& Becker, L., 2012, Developing research proposals, Sage, London.

Engelbrecht, E., 2014, 'Business rescue', paper presented at the Business Rescue Seminar, University of Pretoria, Pretoria, 07 October 2014.

Floor, J., 2013, Business rescue: Is there a reasonable prospect for a successful rescue? Floor Swart Inc., viewed 01 October 2014, from http://www.floorswart.com/ insight.aspx?id=1006

Giacomino, D.E. \& Mielke, D.E., 1993, 'Cash flows: Another approach to ratio analysis', Journal of Accountancy 175(3), 55.

Gillman, L.F., 2001, Due diligence: A financial and strategic approach, Butterworths, Durban.

Gribnitz, K.J. \& Appelbaum, R.L., 2015, G \& A compass methodology to business rescue and compromise offers, G\&A Compass Publishing, Johannesburg.

Holtzhauzen, G., 2010, Modelling business turnaround strategies using verifier determinants from early warning signs theory, University of Pretoria, Pretoria.

IFRS Official Website, International accepted financial ratios, viewed 26 October 2014 from http://www.ifrs.org/Pages/default.aspx

Jooste, L., 2006, 'Cash flow as a yardstick for evaluating financial performance in African businesses', Journal of Managerial Finance 32(7), 569-579. https://doi. org/10.1108/03074350610671566

Joubert, T., 2013, 'Reasonable possibility versus reasonable prospect: Did business rescue succeed in creating a better test than judicial management?', Journal of Contemporary Roman-Dutch Law 76, 550-563.

Katz, J.J., 1998, Realistic rationalism, Massachusetts Institute of Technology, Cambridge.

Lee, Y.W., Pipino, L., Strong, D.M. \& Wang, R.Y., 2004, 'Process-embedded data integrity', Journal of Database Management 15(1), 87-103. https://doi.org/10.4018/ jdm.2004010104

Le Roux, I., Pretorius, M. \& Millard, S., 2006, 'The influence of risk perception, misconception, illusion of control and self-efficiency on the decision to exploit venture opportunity', Southern Africa Business Review 10(1), 51-69.

Levenstein, E., 2008, 'Business rescue: Help is at hand', Without Prejudice, 8(10): 12-14.

Loewenstein, G.F., Thompson, L. \& Bazerman, M.H., 1989, 'Social utility and decision making in interpersonal contexts', Journal of Personality and Social Psychology 57, 426-441. https://doi.org/10.1037/0022-3514.57.3.426

Loubser, A., 2010, 'The business rescue proceedings in the Companies Act of 2008: Concerns and questions (part 1)', TSAR 3, 501-514. 
Maedche, A.D., 2002, Ontology learning for a systematic web, Kluwer Academic, New York. Nieman, G. \& Pretorius, M., 2004, Managing growth: A guide for entrepreneurs, Juta, Cape Town.

Oakdene Square Properties (Pty) Ltd v Farm Bothasfontein (Kyalami) (Pty) Ltd (609/2012) ZASCA 68.

Paston, K.M., Harmon, W.K. \& Gramlich, J.D., 2011, 'A test of financial ratios as predictors of turnaround versus failure among financially distressed firms', Journal predictors of turnaround versus failur
of Applied Research 10(1), 41-56.

Pretorius, M., 2014, 'A competency framework for the business recue practitioner profession', Acta 12(2), 87-107.

Pretorius, M. \& Holtzhauzen, G.T.D., 2008, 'Critical variables of venture turnaround: A liabilities approach', Southern Business Review 12(2), 87-107.

Pretorius, M. \& Holtzhauzen, G.T.D., 2013, 'Business rescue decision making through verifier determinants: Ask the specialists', South African Journal of Economic and Management Sciences 16(4), 468-485. https://doi.org/10.4102/sajems.v16i4.450

Pretorius, M. \& Rosslyn-Smith, W., 2014, 'Expectations of a business rescue plan: International directives of chapter 6 implementation', Southern African Review $18(2), 108-122$.

Republic of South Africa, 2008, Companies Act No. 71 of 2008, Government Gazette, 32121(421), Government Printer, Pretoria.

Rosslyn-Smith, W. \& Pretorius, M., 2015, Stakeholder expectations of the business rescue plan from a South African perspective, The Southern African Journal of Entrepreneurship and Small Business Management 7, 1-35. https://doi. org/10.4102/sajesbm.v7i1.4
Shepherd, D.A., 1999, 'Venture capitalists' assessment of new venture survival', Management Sciences 45(5), 621-632.

Shepherd, D.A., 2005, 'The theoretical basis for my plenary speech about our success and failures at research on business failure'. Proceedings: Regional frontiers of entrepreneurial research, Brisbane, February, 12-14, 2015, pp. 123-134.

Southern Palace Investments 265 (Pty) Ltd v Midnight Storm Investments 386 (Pt) Ltd (15155/2011) ZAWCHC 442; 2012 (2) SA 423 (WCC)

Stiglitz, J.E., 2000, 'The contributions of the economics of information to the twentieth century economics', Quarterly Journal of Economics 115, 1441-1478. https://doi. org/10.1162/003355300555015

Swart v Beagles Run Investments 25 (Pty) Ltd and Others (2011 (5) SA 422 (GNP)) ZAGPPHC 103; 26597/2011.

Timmons, J.A. \& Spinelli, S., 2003, New venture creation: Entrepreneurship for the 21st century, 6th edn., McGraw-Hill, New York, NY.

United Kingdom, 2006, Companies Act of 2006, viewed 15 March 2013, from legislation.gov.uk.

Wang, R.Y., 1998, 'A product perspective on total data quality management', Communications of the ACM 41(2), 58-65. https://doi.org/10.1145/269012.269022

Wang, R.Y., Ziad, M. \& Lee, Y.W., 2006, Data quality, Kluwer Academic Publishers, New York, Boston, MA.

Yin, R.K., 2003, Case study research. Design and methods: Applied social research methods, 3rd edn., Sage, London. 